\title{
LIFE BEYOND DEATH: REGULATING POSTHUMOUS REPRODUCTION IN NEW ZEALAND
}

\author{
Nicola Peart*
}

This article argues that the current legal regulation of posthumous reproduction in New Zealand is deficient. Posthumous reproduction raises issues in relation to consent, the welfare and status of the child, and even such practical issues as succession rights and estate administration. Drawing on Australian and English case law and legislation, this article proposes reform of the current legal regulation to clarify the consent requirements for collection and use of gametes after the death of the gamete provider, and to address the legal status and associated rights of posthumously conceived children.

\section{INTRODUCTION}

On 10 April 2014, the High Court granted a declaration that the removal, transfer and storage of sperm collected from a comatose man was lawful. ${ }^{1}$ The man, whom I shall call Tom, ${ }^{2}$ had suffered a cardio-respiratory arrest, which left him with a severe irreversible hypoxic brain injury resulting from lack of blood flow during the arrest. He was on mechanical life support. His wife, whom I shall call Jane, ${ }^{3}$ wanted the doctors to retrieve some of Tom's sperm so that she would have the chance of having another child. They had a daughter and had been trying to have a second child when Tom had his heart attack. In the absence of written consent from Tom, the hospital was

* Professor of Law, University of Otago. I am indebted to Andrew Snoddy JD, Research Assistant, Faculty of Law, University of Otago. I am also very grateful to my colleague Professor Mark Henaghan for his thoughtful comments on an earlier draft and to Alison Douglass, Barrister and Chair of the Advisory Committee on Assisted Reproductive Technology; Margaret Casey QC, barrister; Dr Jeanne Snelling, Research Fellow, Bioethics Centre, University of Otago; and Dr Lynley Anderson, Senior Lecturer, Bioethics Centre, University of Otago, for discussing curly issues with me, which helped to formulate my thinking on this topic. Any remaining errors are of course mine.

$1 \quad$ Re $M$ [2014] NZHC 757.

2 Fictional names are used to protect the privacy of the parties involved.

3 Fictional names are used to protect the privacy of the parties involved. 
advised not to proceed without a court order authorising the removal and storage of Tom's sperm. Jane made the application. The medical team provided an affidavit stating that Tom lacked the capacity to consent and would not regain capacity. The medical opinion was that Tom could not survive the severe brain injury and that life-sustaining treatment should be withdrawn with the expectation that Tom would die. Jane swore an affidavit that Tom would have consented to the removal of his sperm to preserve the chance of her having his child, a full sibling for their daughter. Based on this evidence, the Court was satisfied that the application should be granted.

This is the first such case to come before a New Zealand court. ${ }^{4}$ But there are several examples of posthumous collection and use of gametes in other common law jurisdictions. ${ }^{5}$ They raise a range of legal and ethical issues, none of which could be fully considered in $\operatorname{Re} M$ because of the urgency of the matter. While the doctors caring for Tom agreed to continue mechanical ventilation for a short time to allow Jane to obtain approval for the removal of sperm, they warned that he could die at any time.

The availability of assisted reproductive procedures has made posthumous conception a realistic possibility. Sperm can be collected before or shortly after death, and stored for posthumous reproductive purposes. ${ }^{6}$ When sperm is collected in these circumstances, it is usually the deceased's widow or female partner who later seeks to use the sperm to have the deceased's child. But in New Zealand we now also have the possibility of an application for the posthumous use of stored sperm by the partner of a family member of the deceased man. ${ }^{7}$

4 In 2006 the Ethics Committee on Assisted Reproductive Technology declined a widow's application to retrieve sperm from her deceased husband, among other things because he had not consented to the collection: Advisory Committee on Assisted Reproductive Technology Annual Report 2006-2007: Including the 2006/07 Annual Report of the Ethics Committee on Assisted Reproductive Technology (Advisory Committee on Assisted Reproductive Technology, 2007) at Appendix 1.

5 English and Australian examples include $R v$ Human Fertilisation and Embryology Authority, ex $p$ Blood [1997] 2 WLR 806 (CA); L v Human Fertilisation and Embryology Authority [2008] EWHC 2149 (Fam), [2009] Eu LR 107; Re Gray [2000] QSC 390, [2001] 2 Qd R 35; Y v Austin Health [2005] VSC 427; Re Edwards [2011] NSWSC 478, (2011) 81 NSWLR 198; Re H, AE [2012] SASC 146; Re Section 22 of the Human Tissue and Transplant Act 1982 (WA), ex p C [2013] WASC 3; and Ping Yuan v Da Yong Chen [2015] NSWSC 932.

6 S Kerr and A Kaplan "Postmortem sperm procurement (1997) 157 J Urol 2154; and Anne M Jequier and Melissa Zhang "Practical problems in the posthumous retrieval of sperm" (2014) 29 Hum Reprod 2615.

7 See the widely publicised case involving an application for the posthumous use of Cameron Duncan's stored sperm: Kirsty Wynn "Frozen sperm battle after tragedy" The New Zealand Herald (online ed, Auckland, 4 January 2015); and Deirdre Mussen "Fight to allow dead boy to father child" Sunday Star Times (New Zealand, 21 December 2014) at 1. 
Posthumous collection of eggs is technically more complicated than posthumous collection of sperm. ${ }^{8}$ The woman requires hormone treatment prior to removal of her ova. To maintain her bodily functions while treatment is provided, she will have to be kept alive by artificial means for days or even weeks. ${ }^{9}$ Furthermore, until very recently, the use of cryopreserved eggs for reproductive purposes was still in the experimental stage. ${ }^{10}$ Posthumous use of eggs will also inevitably require donation of the eggs to create an embryo in vitro for implantation into another woman. ${ }^{11}$ The involvement of a third party adds a further layer of difficulty to the already complex issues surrounding posthumous reproduction. Given these differences, it is not surprising that posthumous collection and use of sperm is treated differently from posthumous collection and use of eggs. ${ }^{12}$

As posthumous collection and use of eggs is still uncommon, it will receive only limited consideration in this article. The primary focus is on the legal issues arising from the posthumous collection of sperm, and the posthumous use of stored sperm or embryos by the deceased man's widow or surviving female partner. For the sake of convenience, the term "widow" is used to include a surviving female partner of a deceased man. Similarly, the term "husband" or "widower" includes an unmarried male partner of a woman.

8 Adrian Blomfield "Family given permission to extract eggs from ovaries of dead daughter world first" The Telegraph (Jerusalem, 8 August 2011), reporting a decision of an Israeli Court granting permission to retrieve eggs and ovarian tissue from a 17 year old brainstem dead woman. David Greer and others "Case 21-2010 - A Request for Retrieval of Oocytes from a 36-Year-Old Woman with Anoxic Brain Injury" (2010) 363 N Engl J Med 276.

9 The difficulties and effects of artificially maintaining bodily functions after death is graphically described in PP v Health Service Executive [2014] IEHC 622 where a woman, who was 15 weeks pregnant when she was declared brainstem dead, was kept alive artificially for three more weeks because her unborn child had a right to life under art 40(3) of the Irish Constitution. However, the High Court of Ireland authorised the withdrawal of all artificial life sustaining measures, because there was no realistic possibility that the foetus could be kept alive until it reached a gestational age when it could be born alive.

10 N Noyes, E Porcu and A Borini "Over 900 oocyte cryopreservation babies born with no apparent increase in congenital anomalies" (2009) 18 Reprod Biomed Online 769. In a subsequent article, Noyes argued that in view of the dramatic increase in live births using frozen eggs, it was time to revisit the oocyte cryopreservation's designation as an experimental procedure: N Noyes, J Boldt and ZP Nagy "Oocyte cryopreservation: is it time to remove its experimental label?" (2010) 27 J Assist Reprod Genet 69.

$11 R$ (on the application of $M$ ) v Human Fertilisation and Embryology Authority [2015] EWHC 1706 (Admin), [2015] Fam Law 1048, where posthumous fertilisation of a woman's eggs and implantation in her mother was declined for lack of clear consent to the donation.

12 Human Assisted Reproductive Technology Order 2005, sch, pt 2, cls 5 and 7. See further Part III below, where the English and Australian law is discussed. Victoria is the only jurisdiction so far to refer explicitly to the collection and use of eggs from a deceased woman: Assisted Reproductive Treatment Act 2008 (Vic), pt 5 . 
Posthumous reproduction raises questions about consent and the scope of autonomy, the welfare and status of the child, and even such practical issues as succession rights and estate administration. Many of the issues are not new, but the context in which they arise calls for fresh consideration.

Professor Bill Atkin has played a prominent role in the development of legal policy in the fast developing field of assisted reproductive technology. Together with Dr Paparangi Reid, then a health researcher at the Wellington School of Medicine, Atkin was appointed to a Ministerial Committee in 1993 to study and report on assisted reproductive technologies. ${ }^{13}$ Their Report identified eight principles, which they called "navigation points", to guide the development of assisted reproductive policy. They also recommended a regulatory framework that was flexible and capable of responding to rapid changes in scientific technology. ${ }^{14}$ They referred to the possibility of harvesting sperm and ova from dead people and identified the need for in-depth ethical review of such procedures. ${ }^{15}$ They also mentioned the growing controversy over the legal status of stored gametes and embryos. Were they property or did they have personality? Atkin and Reid did not favour either approach and recommended instead an approach based on consent: the gamete providers should be granted dispositional power. ${ }^{16}$ While New Zealand has yet to state its position on the legal status of gametes and embryos, the current policy in relation to their use during the lifetime of the gamete providers is broadly consistent with the consent model recommended by Atkin and Reid. ${ }^{17}$

Since that Report, Atkin has continued his work on assisted reproductive technology. His published and unpublished work has helped to formulate current policy on complex legal and ethical questions about assisted reproductive technologies and the consequences for families and society as a whole. ${ }^{18}$ Given Atkin's expertise in this area and his reputation internationally as a leading

13 Report of the Ministerial Committee on Assisted Reproductive Technologies, prepared by WR Atkin and MJP Reid Assisted Human Reproduction - Navigating our Future (1994).

14 At Executive Summary.

15 At 18 .

16 At 97.

17 See for example Advisory Committee of Assisted Reproductive Technology Guidelines on Embryo Donation for Reproductive Purposes (2008).

18 Publications include: Bill Atkin "Medico-legal implications of ART" (1994) 1 BFLJ 90; Bill Atkin "Assisted human reproduction" in Rights and Responsibilities: Papers from the International Year of the Family Symposium on Rights and Responsibilities of the Family) (International Year of the Family Committee, in association with the Office of the Commissioner for Children, Wellington, 1994) 210; Bill Atkin and CA Bridge "Establishing legal relationships: parents and children in England and New Zealand" (1996) 17 NZULR 13; Bill Atkin "Green light for surrogacy in New Zealand" (1998) 2 Childrenz Issues 23; Bill Atkin "Editorial: Blood lines?" (1998) 2 BFLJ 299; Bill Atkin "Regulation of assisted human reproduction: the recent New Zealand model in comparison with other systems" (2005) 11 Revue Juridique Polynésienne 81; and Bill Atkin "Assisted human reproduction: New Zealand's 'third way" model" in L Wardle and C Williams (eds) Family Law: Balancing Interests and Pursuing Priorities (Hein Co, Buffalo 
authority in the broader field of Family Law, it is with some trepidation that I contribute this article to a volume in his honour. I have learned a great deal from reading Atkin's work and talking with him over many years. I am indebted to him and delighted to have this opportunity to acknowledge his generosity and excellence as a teacher, researcher, colleague and friend.

This article addresses the legal issues arising in posthumous reproduction in three parts. Part II analyses the current law in New Zealand. It begins with a brief overview of the legislative framework established by the Human Assisted Reproductive Technology Act 2004 and then explores how posthumous reproduction is regulated in New Zealand. Part III provides an international perspective on posthumous collection and use of gametes for reproductive purposes. Part IV explores key issues arising in the context of posthumous reproduction and makes suggestions as to how the law might respond to these issues.

\section{CURRENT NEW ZEALAND LAW}

\section{A The Law Governing Assisted Reproductive Technology in New Zealand}

All assisted reproductive procedures carried out in New Zealand are subject to the Human Assisted Reproductive Technology Act 2004 (HART Act). ${ }^{19}$ Its purposes include securing the benefits of assisted reproductive technology, prohibiting unacceptable procedures, and providing a robust and flexible framework for regulating the performance of assisted reproductive procedures in New Zealand. ${ }^{20}$ The Act prohibits only a small number of procedures, such as the commercial supply of human gametes and embryos, commercial surrogacy and the implantation of a cloned or hybrid embryo. ${ }^{21}$ For the most part, Parliament has left the development of assisted reproductive policy to the Advisory Committee on Assisted Reproductive Technology (ACART). ${ }^{22}$ This Committee is charged with issuing guidelines and advice on the basis of which the Ethics

(NY), 2007) 213. Submissions include: Tony Angelo and Bill Atkin "Submissions to the Justice and Law Reform Committee on the Status of Children Amendment Bill 1986"; and Bill Atkin "Submission to the Health Select Committee on Supplementary Order Paper No 80: Human Assisted Reproductive Technology Bill and Assisted Human Reproduction Bill".

19 For a more detailed consideration of this Act, see Nicola Peart "Alternative Means of Reproduction" in PDG Skegg and Ron Paterson (eds) Health Law in New Zealand (Thomson Reuters, Wellington, 2015) at ch 17. For a comparative analysis see Bill Atkin "Regulation of assisted human reproduction: the recent New Zealand model in comparison with other systems", above n 18.

20 Human Assisted Reproductive Technology Act 2004, s 3.

21 Sections 8,13 and 14 .

22 Sections 32 and 35. 
Committee on Assisted Reproductive Technology (ECART) approves applications for assisted reproductive procedures on a case-by-case basis. ${ }^{23}$

The Act lists seven principles that must guide all persons exercising powers or performing functions under the Act: ${ }^{24}$

(a) the health and well-being of children born as a result of the performance of an assisted reproductive procedure or an established procedure should be an important consideration in all decisions about that procedure:

(b) the human health, safety, and dignity of present and future generations should be preserved and promoted:

(c) while all persons are affected by assisted reproductive procedures and established procedures, women, more than men, are directly and significantly affected by their application, and the health and well-being of women must be protected in the use of these procedures:

(d) no assisted reproductive procedure should be performed on an individual and no human reproductive research should be conducted on an individual unless the individual has made an informed choice and given informed consent:

(e) donor offspring should be made aware of their genetic origins and be able to access information about those origins:

(f) the needs, values, and beliefs of Maori should be considered and treated with respect:

(g) the different ethical, spiritual, and cultural perspectives in society should be considered and treated with respect.

In 2005, on the recommendation of the Minister of Health, given after receiving advice from ACART, the Governor-General made an Order in Council declaring certain assisted reproductive procedures "established procedures". ${ }^{25}$ They are excluded from the definition of "assisted reproductive procedure", ${ }^{26}$ which allows them to be performed without approval from ECART. ${ }^{27}$

23 Sections 16,19 and 28.

24 Section 4.

25 Section 6.

26 Section 5.

27 Section 16 requires ethical approval for "assisted reproductive procedures", which excludes established procedures: s 5. To the extent that there is uncertainty about an established procedure, the Ethics Committee on Assisted Reproductive Technology is empowered to provide an informal opinion. This function was added to the functions listed in Human Assisted Reproductive Technology Act 2004, s 28(1): Notice from the Minister of Health to the Ethics Committee on Assisted Reproductive Technology (23 February 2011); 
For example, the HART Order declared artificial insemination an established procedure if it uses the sperm of the woman's husband, or sperm donated by her husband's brother or cousin or by a stranger. ${ }^{28}$ Certain in vitro procedures are also established procedures, such as the creation of embryos using a couple's gametes, or the gamete of one of them and a gamete donated by a stranger. ${ }^{29}$ These procedures were by then part of routine clinical practice and broadly accepted by society. The HART Order has since been amended to increase the range of established procedures as they have become scientifically possible and acceptable to society. ${ }^{30}$

ACART has issued guidelines on a range of assisted reproductive procedures. ${ }^{31}$ Only the Guidelines on the Use, Storage and Disposal of Sperm from a Deceased Man are directly relevant to posthumous conception. They were developed in 2000 by ACART's predecessor, the National Ethics Committee on Assisted Human Reproduction, well before the HART Act and HART Order were adopted. The Guidelines deal with posthumous conception to only a limited extent and have in part been superseded by the HART Act and the HART Order. ${ }^{32}$ None of the other guidelines refer specifically to the posthumous collection of gametes or the posthumous use of gametes or embryos. They are nonetheless relevant to the various ways in which gametes or embryos might be used after the death of the gamete provider.

Letter from Don Gray (Deputy Director-General, Policy Business Unit, Ministry of Health) to Kath Moran (Manager Family Law Section, New Zealand Law Society) (21 January 2014).

28 Human Assisted Reproductive Technology Order 2005, cls 3, 4 and 5.

29 Clauses 3,4 and 5.

30 For example, the Human Assisted Reproductive Technology Amendment Order 2009 declared the use of frozen human eggs an established procedure if the eggs are to be used while the woman from whom the eggs were retrieved is alive. The Human Assisted Reproductive Technology Amendment Order 2011 declared the collection of immature eggs and the use of in vitro matured eggs established procedures.

31 The Advisory Committee on Assisted Reproductive Technology has issued the following guidelines: Guidelines on Embryo Donation for Reproductive Purposes (2008); Guidelines on Surrogacy involving Assisted Reproductive Procedures (2013); Guidelines on the Creation and Use, for Reproductive Purposes, of an Embryo created from Donated Eggs in conjunction with Donated Sperm (2010); Guidelines on Donation of Eggs or Sperm between Certain Family Members (2013); Guidelines on Preimplantation Genetic Diagnosis with Human Leucocyte Antigen Tissue Typing (2014).

32 The Advisory Committee on Assisted Reproductive Technology reissued the National Ethics Committee on Assisted Human Reproduction's Guidelines on the Use, Storage and Disposal of Sperm from a Deceased Man (2000) in 2007: (29 November 2007) 8262 New Zealand Gazette 3375. A review of these guidelines is included in the Advisory Committee on Assisted Reproductive Technology's current work programme. 


\section{B The Current Legal Regulation of Posthumous Conception}

The legal regulation of posthumous conception is complex, uncertain and incomplete. Some procedures are prohibited, ${ }^{33}$ some are established procedures, ${ }^{34}$ while others are regulated procedures requiring approval from ECART. ${ }^{35}$ Many of the issues that are central to posthumous conception have yet to be fully considered by ACART and Parliament, such as the consent requirements, whether the use of gametes collected from a deceased person should be limited to the deceased's spouse or partner, the welfare of a child conceived after the death of its biological parent, the child's status, and rights associated with status, such as succession and beneficial interests in trusts. Posthumous use of gametes is one of the matters that ACART is required to provide advice on to the Minister of Health, but revision of the Guidelines on the Use, Storage and Disposal of Sperm from a Deceased Man is not part of ACART's current work programme.

\section{Collection of gametes from a comatose ${ }^{36}$ or deceased person}

Both the collection of eggs from a comatose or deceased woman and the collection of sperm from a comatose or deceased man are established procedures and can therefore be carried out without approval from ECART. The HART Order lists the collection of sperm and eggs as established procedures without limiting it to living people, ${ }^{37}$ whereas it does distinguish between the living and the dead when it comes to the posthumous use of these gametes. ${ }^{38}$

(a) Consent to collection from a comatose person

One of the HART Act's principles is that "no assisted reproductive procedure should be performed on an individual ... unless the individual has made an informed choice and given informed consent". ${ }^{39}$ The Act does not expand on this principle, so it is unclear how specific the consent must be or how it should be evidenced. The use of the word "should", rather than an

33 For example, the prohibition on use of gametes collected from a minor under the age of 16: Human Assisted Reproductive Technology Act 2004, s 12.

34 For example, Human Assisted Reproductive Technology Order 2005, sch, pt 1 in regard to collection of gametes, and pt 2, cl 5 in relation to posthumous use of sperm.

35 For example, the use of donated sperm with donated eggs is excluded from the list of established procedures: Human Assisted Reproductive Technology Order 2005, sch, pt 2, cl 1. The Ethics Committee on Assisted Reproductive Technology can grant ethical approval based on the Advisory Committee on Assisted Reproductive Technology's Guidelines on the Creation and Use, for Reproductive Purposes, of an Embryo created from Donated Eggs in conjunction with Donated Sperm (2010).

36 The word "comatose" is used to refer to a person who is highly unlikely to regain competence. In most cases death is imminent, as in $\operatorname{Re} M$, above $\mathrm{n} 1$.

37 Human Assisted Reproductive Technology Order, sch, pt 1.

38 Schedule, pt 2, cls 5 and 7.

39 Human Assisted Reproductive Technology Act 2004, s 4(d). 
outright prohibition, also suggests that there may be circumstances where consent might be given by someone else, such as someone who is legally entitled to consent on behalf of the individual or the court.

ACART's Guidelines on the Storage, Use and Disposal of Sperm from a Deceased Man predate the HART Act and were developed to deal with the posthumous use of sperm collected and stored when the man was alive and competent to determine the posthumous use of his sperm. In regard to the collection of sperm, the Guidelines merely express the Committee's view that "collection of sperm from a comatose or recently deceased person without that person's prior written consent is ethically unacceptable"..$^{40}$ In Re $M$, Tom had not given written consent to the removal of his sperm while he was comatose. On ECART's advice, Jane applied for a declaratory order that the retrieval of sperm from her husband was lawful. The Court granted the application based on the supporting affidavits from Jane and the consultant in charge of Tom's treatment, but without setting out the legal foundation for making the order, because the circumstances were extremely urgent. ${ }^{41}$

If Tom had been competent, the Code of Health and Disability Services Consumers' Rights (Code of Rights) would have applied in the absence of any other law governing the provision of a health service to a living person. ${ }^{42}$ Right $7(1)$ of the Code of Rights would have required his informed consent. ${ }^{43}$ But Tom was not competent and would not regain competence. Nor did he appear to have a welfare guardian or a person with an enduring power of attorney who could have given consent on his behalf, ${ }^{44}$ leaving aside for the moment whether a decision about reproduction can or should ever be made by someone else. ${ }^{45}$ In the absence of consent from the patient or

40 Advisory Committee on Assisted Reproductive Technology Guidelines on the Use, Storage and Disposal of Sperm from a Deceased Man (2000) at [2.3].

41 The application was made under the Declaratory Judgments Act 1908, but it seems that the Court exercised its inherent jurisdiction to make the order. The application did not refer to any statute, regulation or other written instrument that required construction to determine the legality of retrieving of sperm from a comatose person: Declaratory Judgments Act 1908, s 3 .

42 Health and Disability Commissioner (Code of Health and Disability Services Consumers' Rights) Regulations 1996, promulgated under the Health and Disability Commissioner Act 1994, s 74(1). See further PDG Skegg "Consent to treatment" in Skegg and Paterson (eds), above n 19, at ch 6.

43 Code of Rights, Right 7(1). A person is presumed to be competent to consent unless there are reasonable grounds for believing otherwise: Right 7(2). See Skegg, above n 42.

44 Code of Rights, Right 7(4). For example, a welfare guardian or a person appointed under an enduring power of attorney in relation to personal care and welfare: Protection of Personal and Property Rights Act 1988, s 12 and s 98 respectively. But note that in each case the appointee's paramount duty is to promote and protect the welfare and best interests of the person for whom the welfare guardian or attorney is acting: ss 18(3) and 98A.

45 The Mental Capacity Act 2005 (UK), s 27(1)(h) prohibits anyone giving consent under the Human Fertilisation and Embryology Acts 1990 and 2008 (UK) on behalf of a person lacking capacity to consent. 
someone entitled to consent on the patient's behalf, Right 7(4) permits healthcare providers to treat a patient if it is in the patient's best interests and consistent with the patient's views or, if the patient's views cannot be ascertained, the provider takes account of the views of other suitable persons who are interested in the patient's welfare.

Some might justifiably question whether retrieving gametes from an incompetent person for purposes of posthumous reproduction is ever in the best interests of the patient. They might argue that the patient derives no direct personal benefit from the procedure. It could even harm the patient. Nor should consent to posthumous conception be inferred from a couple's decision to try and have a child during their lifetime. Conceiving a child during one's lifetime, in which one would normally expect to play a parental role, is very different from agreeing to a child being conceived after one's death. The deceased could never have a relationship with the child and the child would never know his or her biological father other than through stories and pictures.

Others might argue that retrieval of gametes from an incompetent person could be in the best interests of the patient. There may be evidence that the patient or the couple had contemplated posthumous conception. ${ }^{46}$ Alternatively, the patient's consent may be inferred from the patient's views and values, and the surrounding circumstances. For example, the patient may have wanted a child to carry on the family name or the family farm. Or the patient and his partner may already have one child and been trying for a second child, because they believed a sibling for their first child would be in the best interests of the first child and their family.

There are good arguments going both ways and they rely on a range of factors other than prior written consent. While the Code of Rights permits a wider enquiry, there is a risk that best interests will be construed narrowly and prevent collection of gametes from a comatose patient for purposes of posthumous conception.

Similar problems could occur if a welfare guardian, or a person appointed under an enduring power of attorney, or the court, were called upon to exercise their powers under the Protection of Personal and Property Rights Act 1988. Although that Act does not explicitly prohibit consent being given to the carrying out of assisted reproductive procedures on behalf of a person lacking capacity, ${ }^{47}$ it stipulates that any power be exercised only if it promotes the welfare and best interests of the incompetent person. ${ }^{48}$ There is a risk that the retrieval of gametes from an incompetent

46 As in Re Edwards, above n 5.

47 In contrast to the Mental Capacity Act 2005 (UK), s 27(1)(h), which explicitly prohibits consent being given under the Human Fertilisation and Embryology Acts 1990 and 2008 (UK) on behalf of a person lacking capacity.

48 Protection of Personal and Property Rights Act 1988, ss 8, 10, 12 and 18 in relation to welfare guardians and ss 98 and 98A in relation to enduring powers of attorney. See also $\operatorname{Re} H$ [1993] NZFLR 225 (FC); Re A, $B$ and C (Personal Protection) [1996] 2 NZLR 354 (HC); and KR v MR [2004] 2 NZLR 847 (HC). 
person for posthumous use may never be seen as promoting the incompetent person's welfare and best interests. ${ }^{49}$ As with the Code of Rights, the scope of those interests might be construed too narrowly to allow for posthumous conception.

The risk is even greater if the court's inherent parens patriae jurisdiction is invoked. ${ }^{50}$ The purpose of that jurisdiction is to protect persons who are unable to look after themselves. ${ }^{51}$ The jurisdiction is founded on the principle of necessity and must be exercised with great caution for the benefit of the vulnerable person, not for the benefit of others. In the medical context it must be used to promote the health and welfare of the vulnerable person. ${ }^{52}$ It was used to that end in $\operatorname{Re} G$ to authorise the withdrawal of nutrition and hydration from a man in an almost permanent vegetative state, because his view of life was wholly inconsistent with the provision of ongoing treatment. ${ }^{53}$ But it is difficult to argue that authorising the removal of sperm from a dying man is necessary for his protection or welfare. ${ }^{54}$

It will be even more difficult to argue that the collection of eggs from an incompetent woman for posthumous use by her husband is in her best interests or that it promotes her welfare. The use of her eggs would inevitably require a surrogacy arrangement and, if the surrogate mother agrees to hand over the child to the deceased woman's husband, he would have to go through an adoption process to become the child's father. ${ }^{55}$ While the deceased woman would be the biological mother

49 Note the uncertainty expressed by the Supreme Court of New South Wales in Ping Yuan v Da Yong Chen, above $\mathrm{n}$ 5, as to whether its declaration granted under urgency under the Guardianship Act 1987 (NSW) authorising the removal of sperm from an unconscious dying man was lawful. After further consideration the Court acknowledged that it may not have been Parliament's intention to allow a wife to consent to the removal of sperm from her dying husband.

50 Judicature Act 1908, s 16 confers on the High Court all the jurisdiction it had when the Act came into operation and all the jurisdiction necessary to administer the laws of New Zealand. The equivalent provision in the Australian statutes has been relied on to make declarations authorising the removal of sperm from deceased men. See further below. Judicature Act 1908, s 17 explicitly preserves the High Court's inherent parens patriae jurisdiction, which may be invoked only if there is no statutory jurisdiction or when justice requires it: Carrington v Carrington [2014] NZHC 869, [2014] NZFLR 571 at [45]-[46].

51 At [10]-[19], relying on a decision of the Supreme Court of Canada in Re Eve [1986] 2 SCR 388 at 389 390 .

52 MAWv Western Sydney Area Health Service (2000) 49 NSWLR 231 (NSWSC) at [31].

$53 \operatorname{Re} G[1997] 2$ NZLR $201(\mathrm{HC})$.

54 That was the conclusion of the Court in MAWv Western Sydney Area Health Service, above n 52.

55 A surrogacy arrangement is not enforceable by or against any person: Human Assisted Reproductive Technology Act 2004, s 14(1). The child would be the child of the surrogate mother and her partner, if her partner consented to the surrogacy arrangement: Status of Children Act 1969, ss 17 and 18. 
of the child, she could not become the child's legal parent under the current law. ${ }^{56}$ Arguing that any of these processes is in her best interests is problematic.

Given the uncertainty about the authorisation for collection of gametes from a comatose person, clarification of the law is desirable.

(b) Consent to collection from a deceased person

If the person from whom the gametes are to be collected is dead, the Code of Rights does not apply. ${ }^{57}$ The court can also not rely on its parens patriae jurisdiction. It does not apply to dead bodies. ${ }^{58}$ In the absence of statutory authority, it is not clear whether anyone has a right to remove gametes from a dead body. The Queensland Supreme Court has expressed divergent opinions. In Re Gray, Chesterman J could find no legal basis that would give it jurisdiction to make an order permitting the removal of sperm from a dead man. ${ }^{59}$ There is a duty to dispose of the body, for which limited purpose the executor has the right to possess it, but beyond that there is no property in a body. ${ }^{60}$ Furthermore, his Honour thought it was at least arguable that removing part of the testicles of a dead man would be an improper or indecent interference with, or indignity to, a dead human body, which is a criminal offence in Australia as well as New Zealand. ${ }^{61}$ The Court in Baker $v$ Queensland agreed. ${ }^{62}$ But in Re Denman Atkinson J disagreed. ${ }^{63}$ Nothing was outside the High Court's inherent jurisdiction unless it was expressly excluded. ${ }^{64}$ As there was no statutory prohibition on the removal of sperm from a deceased person, the Court held that it had the necessary jurisdiction to decide whether the proposed act was lawful. In view of the urgency, Atkinson $\mathbf{J}$ treated the question as akin to an interlocutory injunction. As there were good policy arguments for and against making the order, there was a serious question to be tried and the balance of convenience clearly favoured granting the order so that its use could be determined at a later

56 As she is dead, she is no longer a person or a spouse who could adopt the child: Adoption Act 1955, s 3. Her surviving husband could apply to adopt the child on his own. The child will then be his child for all purposes: Adoption Act 1955, s 16.

57 PDG Skegg "Removal and Retention of Cadaveric Body Parts: Does the Law Require Parental Consent?" (2003) 10 Otago LR 425 at 436-441.

58 Re Gray, above $\mathrm{n} 5$, at 37.

59 Re Gray, above n 5.

60 Williams v Williams (1882) $20 \mathrm{Ch}$ D 659 at 665; Re Gray, above n 5, at 38-39; and Takamore v Clarke [2012] NZSC 116, [2013] 2 NZLR 733.

61 Re Gray, above $\mathrm{n}$ 5, at 40. The equivalent offence in New Zealand is s 150 of the Crimes Act 1961.

62 Baker v Queensland [2003] QSC 2.

63 Re Denman [2004] QSC 70, [2004] 2 Qd R 595.

64 Relying on McPherson J's observation in Boyd v Halstead, ex p Halstead [1985] 2 Qd R 249 (QSC) at 255. 
stage. ${ }^{65}$ That approach has also been followed, though sometimes acknowledging the uncertainty of the jurisdiction. ${ }^{66}$

Several Australian jurisdictions have been able to sidestep the issue by relying on their human tissue legislation. ${ }^{67}$ Gametes come within the definition of "tissue" as a "substance extracted from a human body", and their collection for reproductive purposes has been held to constitute a "medical purpose" for which tissue may be removed from a dead body. ${ }^{68}$ Consent in accordance with the human tissue legislation then provides the necessary authority to remove gametes from deceased persons.

New Zealand's Human Tissue Act 2008 does not provide the necessary authority. It explicitly excludes human embryos and human gametes from the definition of "human tissue". ${ }^{9}$ The posthumous collection of gametes in New Zealand is thus governed by the common law. In Re M the Court was clearly satisfied that it had jurisdiction to make an order declaring the collection of sperm lawful, but it did not set out the legal foundation for the order. $\operatorname{Re} H, A E,^{70}$ a South Australian decision that followed Re Denman ${ }^{71}$ and relied on its inherent jurisdiction to authorise the removal of sperm from a deceased man, was cited to the Court in Re M. That ruling may have persuaded the Court that it had inherent jurisdiction to make the order. Nonetheless, as the Australian case law suggests, some uncertainty remains whether anyone has the legal authority to consent to the removal of gametes from a deceased person in the absence of statutory authority. ${ }^{72}$ It would therefore be helpful if the law were clarified.

65 The order was made subject to court approval for its future use, a common condition of such orders. See for example Re Edwards, above n 5, where the Court was asked to rule on the widow's application to use the sperm extracted from her deceased husband on the basis of a court order authorising the removal.

66 Fields v Attorney-General of Victoria [2004] VSC 547; Yv Austin Health, above n 5; and Re H, AE, above n 5 .

67 Human Tissue Act 1982 (Vic), as construed in AB v Attorney-General for the State of Victoria [2005] VSC 180 at [109]-[111]; Human Tissue Act 1983 (NSW), as construed in Re Edwards, above n 5, at 203-205; and Human Tissue and Transplant Act 1982 (WA), as construed in Re Section 22 Human Tissue and Transplant Act 1982 (WA), ex $p$ C, above n 5. Use of the gametes for reproductive purposes has been held to be a "medical purpose" in those jurisdictions. In Re Gray, above n 5, the Court held that the removal of sperm did not meet this requirement.

68 For example, Human Tissue and Transplant Act 1982 (WA), ss 3 and 22.

69 Human Tissue Act 2008, s 7.

$70 \operatorname{Re} H, A E$, above n 5.

71 Re Denman, above n 63.

72 See also L $v$ The Human Fertilisation and Embryology Authority, above n 5, at [144]-[161], where the Court doubted whether, in the absence of statutory authority, anyone, including the Court, could authorise the removal of gametes from a deceased person. 


\section{Posthumous use of gametes and stored embryos}

The posthumous use of gametes and stored embryos is equally unclear, both in terms of whether ECART approval is required and the purpose for which they may be used posthumously. The consent requirements are also uncertain for reasons similar to those outlined in relation to collection of gametes.

(a) Posthumous use of sperm

The posthumous use of sperm is an established procedure provided the deceased consented to the "specific use" before he died. ${ }^{73}$ This would normally mean that the sperm was collected while he was alive and competent to consent to the storage of his sperm for subsequent use. When he stored his sperm, he would have been asked to indicate what should happen if he died leaving sperm in storage. ${ }^{74}$ Alternatively, he may have consented to his sperm being collected when he was comatose or after he had died, for purposes of posthumous reproduction. ${ }^{75}$ In that case, the posthumous use would also be an established procedure.

What constitutes "specific use" is unclear. The deceased's consent to his widow using his sperm after his death would clearly meet this requirement. So too if he had specified some other particular person. A donation of sperm is an established procedure if it is made to the donor's brother, cousin or a stranger. ${ }^{76}$ But would it still be an established procedure if the deceased had consented to his sperm being used after his death, without specifying who could use it? A fertility treatment provider who was uncertain as to whether a proposed use of sperm was an established procedure could seek an informal opinion from ECART. ${ }^{77}$

The Guidelines on the Use, Storage and Disposal of Sperm from a Deceased Man limit the posthumous donation of sperm. If the deceased consented to his sperm being donated to a nonspecified person or couple, it may only be used by a person or couple who already had a child using

73 Human Assisted Reproductive Technology Order 2005, sch, pt 2, cl 5. This clause overrides the limits on the posthumous use by a specified person in the Advisory Committee on Assisted Reproductive Technology's Guidelines on the Use, Storage and Disposal of Sperm from a Deceased Man (2000) at [2.2].

74 Advisory Committee on Assisted Reproductive Technology Guidelines on the Use, Storage and Disposal of Sperm from a Deceased Man (2000) at [2.0].

75 Human Assisted Reproductive Technology Order 2005, sch, pt 2, cl 5 refers only to the use of sperm collected from a man who has since died. However, it would make no sense if the use of sperm collected after his death without his consent to its specific use was an established procedure.

76 Schedule, pt 2, $\mathrm{cl} 2$. The donor and the family member receiving the donation must both be at least 20 years old: $\mathrm{cl} 2 \mathrm{~A}$.

77 Notice from the Minister of Health to the Ethics Committee on Assisted Reproductive Technology (23 February 2011); Letter from the Deputy Director-General (Policy Business Unit, Ministry of Health) to the Manager of the Family Law Section (New Zealand Law Society) (21 January 2014). 
the deceased's sperm before he died. ${ }^{78}$ If sperm that could be donated to a non-specified person or couple was not used prior to the donor's death, or if the person or couple who did use it prior to the donor's death did not wish to use it again, the Guidelines state that the sperm must be disposed of in a culturally appropriate manner. ${ }^{79}$ Unless the posthumous donation to an unspecified person or couple comes within the HART Order's meaning of "specific use" so as to override the Guidelines, a deceased man's sperm cannot be used by any unspecified person or couple other than the person or couple who had used it before his death.

(b) Posthumous use of eggs

There is no uncertainty as to the posthumous use of eggs. The HART Order explicitly excludes the posthumous use of eggs from the list of established procedures. It requires ECART approval, even if the woman consented specifically to their posthumous donation for use by another woman, such as her sister. ${ }^{80} \mathrm{Had}$ she been alive, the donation of her eggs to her sister or cousin would have been an established procedure. ${ }^{81}$ As ACART has not issued any guidelines or advice on the posthumous use of a woman's eggs, ECART cannot currently approve any applications for their posthumous donation.

(c) Posthumous use of stored embryos

The implantation into a widow of the couple's stored embryos after her husband's death would appear to be an established procedure if her husband had consented to their implantation after his death. ${ }^{82}$ The donation of such embryos to another woman requires approval from ECART. ACART's Guidelines on Embryo Donation for Reproductive Purposes 2008 do not explicitly address embryo donation after one or both of the gamete providers have died. However, the requirements imply that the donors must be alive when the donation takes place. Posthumous donation of embryos is therefore not lawful in New Zealand. ${ }^{83}$

78 Advisory Committee on Assisted Reproductive Technology Guidelines on the Use, Storage and Disposal of Sperm from a Deceased Man (2000) at [2.1], option a.

79 At [2.1], option b.

80 Human Assisted Reproductive Technology Order 2005, sch, pt 2, cl 7.

81 Schedule, pt 2, cl 2, provided both the donor and recipient were over the age of 20.

82 If the widow's use of her late husband's sperm with his specific consent is an established procedure, then it can be inferred that the implantation of their stored embryos with his specific consent to their posthumous implantation is also an established procedure.

83 Human Assisted Reproductive Technology Act 2004, s 16 makes the performance of an assisted reproductive procedure without approval from the Ethics Committee on Assisted Reproductive Technology an offence. 


\section{Minors under the age of 16}

Section 12 of the HART Act restricts the collection and use of gametes from minors under the age of 16. It provides:

(1) No person may-

(a) obtain a gamete from an individual who is under 16 years; or

(b) use a gamete that has been obtained from an individual who is under 16 years.

(2) Every person commits an offence who contravenes this section and is liable on ... conviction to imprisonment for a term not exceeding 1 year or a fine not exceeding $\$ 100,000$, or both.

(3) It is a defence to a charge of an offence against this section if the defendant proves that the gamete concerned was obtained or used by a person-

(a) to preserve the gamete; or

(b) to bring about the birth of a child that was, in the reasonable opinion of the person, likely to be brought up by the individual from whom the gamete was obtained.

This section is clearly aimed at protecting the vulnerability of minors, whilst at the same time preserving their reproductive capability. Gametes can be retrieved from a minor under 16 years of age to preserve the gamete for the minor's own subsequent reproductive use. Sperm obtained from a minor under 16 can therefore be used by his (future) partner or it can be donated to a surrogate mother for purposes of creating a child to be brought up by the sperm provider. Eggs obtained from a minor under 16 could also be donated for use by a surrogate mother with the intention that any resulting child will be brought up by the woman from whom the eggs were retrieved when she was under the age of 16 .

Aside from donating to a surrogate mother for purposes of producing a child for the gamete provider, s 12 appears to impose a blanket prohibition on the donation of gametes obtained from a minor under the age of 16 . The section could be construed to prevent persons over 16 from donating gametes collected when they were under 16. This is one of the issues in an application by Cameron Duncan's family for the posthumous use of sperm that he banked when he was 15 years old prior to undergoing cancer treatment in $2002 .{ }^{84} \mathrm{He}$ died in 2003 at the age of $17 . \mathrm{He}$ gave his mother written authority to determine what should be done with his sperm if he died. His sister and her female partner wanted to use the sperm to conceive a child, but ECART advised that it could not approve such an application, because it would contravene s $12 .{ }^{85}$ Section 12 could be interpreted to make

84 See Wynn, above n 7; and Mussen, above n 7.

85 Ethics Committee on Assisted Reproductive Technology Minutes of the Fiftieth Meeting (18 September 2014) at [14] (application E14/158). 
such use of his sperm an offence, regardless of his age or competence to make decisions about the posthumous use of his sperm. The mere fact that his sperm was collected when he was under the age of 16 could mean that it could never be donated, not even if Cameron had lived into adulthood and had then wanted to donate sperm that was surplus to his requirements. There appears to be no good reason for such a restrictive interpretation. The purpose of the provision is to protect minors under the age of 16 against exploitation. That purpose is not defeated if the minor, after turning 16, wishes to donate those gametes for use by others. There is thus uncertainty as to the scope of s 12 .

The Guidelines on the Use, Storage and Disposal of Sperm from a Deceased Man pose a further hurdle for the proposed use of Cameron Duncan's sperm. As explained earlier, unless he had specified who could use his sperm after his death so as to come within the HART Order rather than the Guidelines, it could only be used by a person or couple who already had a child using his sperm. Arguably, authorising his mother to determine what to do with his sperm after his death is sufficient to avoid the limitation on subsequent use.

\section{Legal status of a posthumously conceived child}

In $\operatorname{Re} M$, Jane wanted to have the opportunity to have Tom's child, a sibling for their daughter. However, it is by no means clear that any child she may eventually have using Tom's sperm will be legally identified as his child. The legal status of a posthumously conceived child is uncertain. The Status of Children Act 1969 has two relevant parts. Part 1 contains the general presumptions as to parenthood. It states, relevantly, that a child born to a woman within 10 months after the marriage is dissolved by death is presumed to be the child of its mother and her late husband. ${ }^{86}$ This presumption is unlikely to apply to a child conceived after the husband's death, even if the child happened to be born within the time limit. ${ }^{87}$ The 10-month time limit corresponds to the maximum duration of a pregnancy. It implies that conception is presumed to have occurred before the husband's death and that he is therefore presumed to be the father. Where the paternity of a child is unclear, the court has the power to make a declaration of paternity, which may be made after the death of the alleged father on the application of his widow. ${ }^{88}$ If such a declaration could be granted in respect of a child who was conceived posthumously using the deceased husband's sperm, the child would then be the child of its birth mother and her late husband. However, Part 1 predates the development of new birth technologies.

The Status of Children Act was amended in 2004 to insert a new Part 2 to "remove uncertainty about the status of children conceived as a result of AHR procedures". ${ }^{89}$ If this Part applies to

86 Status of Children Act 1969, s 5(1).

87 Fertility clinics generally have a policy of not using the sperm for a year following its collection from a comatose or recently deceased man. See also Re Gray, above n 5, at 36.

88 Status of Children Act 1969, s 10

89 Section 13. 
posthumously conceived children, the deceased would not be the father of the child. An "AHR procedure" is defined to include artificial insemination of a woman where the semen used is produced by a man "who is not her partner". ${ }^{90} \mathrm{~A}$ "partner" is defined as a person to whom the woman "is married or in a civil union". ${ }^{91}$ The use of the present tense excludes a deceased spouse or civil union partner. The marriage or civil union between the birth mother and her late husband or civil union partner ended when he died. A "partnered woman" is also defined in the present tense as a woman "who is married or in a civil union" or who "is living with a man, or with another woman, as a de facto partner". ${ }^{92}$ If the surviving spouse has not re-partnered when she has a child using her late husband's sperm, she will be deemed to be a "woman acting alone" and her late husband is deemed not to be the father of the child for any purpose. ${ }^{93}$ The child has no father in that case. If she has re-partnered, and the artificial insemination procedure is performed with her new partner's consent, the new partner will be deemed to be the father or parent of the child for all purposes.

The two parts of the Act thus produce starkly contrasting results for a posthumously conceived child using sperm of a deceased man. The lack of certainty as to which part applies to posthumously conceived children suggests that Parliament did not consider this possibility.

The Act's rule for determining motherhood is plain: the birth mother is deemed to be the mother of the child, regardless of whose gametes were used to create the child. ${ }^{94}$ If the birth mother was a surrogate, the intending parents can only become the legal parents of the child by adopting the child. As with fatherhood of a posthumously conceived child, Parliament has not considered the possibility of motherhood of a posthumously conceived child. This is another issue that deserves careful consideration. As explained in the next part of this article, Victoria in Australia has changed its legislation governing the status of posthumously conceived children to allow the deceased parent to be registered as the parent of the child. ${ }^{95}$

\section{Succession and other rights associated with the child's legal status}

The uncertain legal status of a posthumously conceived child has consequences for succession law and the administration of the estate of the deceased biological parent. If the deceased is not the parent of the child, the child has no intestate succession rights or eligibility to make a claim for

90 Section 15 (emphasis added).

91 Section 14(1) (emphasis added).

92 Section 14(1).

93 Section 22.

94 Section 17.

95 Status of Children Act 1974 (Vic), ss 37-40. 
provision from the estate under the Family Protection Act $1955 .{ }^{96}$ The deceased would not be the parent of the child for any purpose, according to the Status of Children Act $1969 .{ }^{97}$ Whether the child nonetheless has testamentary rights will depend on the terms of the deceased's will. A gift to the deceased's "children", would not include a posthumously conceived child if the deceased was deemed not to be the child's parent.

If the deceased is the legal parent of the child, the child might have succession rights if the estate has not been finally distributed by the time the child is born. ${ }^{98}$ If the deceased left a valid will, the child's entitlement would again depend on the terms of the will. Whether a posthumously conceived child would be entitled to succeed if its biological parent had died intestate is open to question. Section 77 of the Administration Act 1969 refers to the intestate leaving issue. While "issue" is not defined and therefore could include a posthumously conceived child, it is arguable whether a deceased "leaves" issue if the child was not conceived at the time of the intestate's death. For purposes of the Family Protection Act, on the other hand, the child merely needs to be a "child of the deceased". ${ }^{99}$ In contrast to the eligibility of a grandchild, the Act does not stipulate that a child must be living when the deceased died. ${ }^{100}$ If the deceased had consented to the posthumous conception of his or her child, the deceased would also owe a moral duty to provide for the child's proper maintenance and support. ${ }^{101}$ Nonetheless, clarification of the succession rights of a posthumously conceived child is needed.

The child's uncertain status may also be an issue in other circumstances, such as trusts. In view of the very large number of trusts in New Zealand, will a posthumously conceived child qualify as a member of the class of beneficiaries? This question may not only be relevant to the child, but also to the child's offspring. Grandchildren are commonly included as beneficiaries of a trust.

96 The child would not qualify as "issue" left by the deceased for intestacy purposes: Administration Act 1969, s 77. Nor would the child be a "child" of the deceased for purposes of the Family Protection Act 1955, s 3.

97 Status of Children Act 1969, ss 19-22.

98 The Family Protection Act 1955, s 9 imposes a time limit and prevents an extension of time being granted if the estate has been finally distributed. Final distribution occurs when all the assets in the estate have been transferred to the beneficiaries, not when administration is complete: Family Protection Act 1955, s 2(4). Status of Children Act 1969, ss 5A, 6, 6B and 6C impose duties on administrators and executors to make inquiries as to whether a child exists who would have a claim against the deceased estate. If they have made reasonable inquiries and, without notice of the existence of such a child, distribute the estate, they are protected from liability.

99 Family Protection Act 1955, s 3(1)(b).

100 Family Protection Act 1955, s 3(1)(c). Note also the eligibility requirements for stepchildren and the Supreme Court's ruling in Wood-Luxford $v$ Wood [2013] NZSC 153, [2014] 1 NZLR 451 that for policy reasons "living" meant that the child had to be born at the relevant time and not merely en ventre sa mere.

101 Family Protection Act 1955, s 4. 


\section{INTERNATIONAL PERSPECTIVE}

The posthumous collection of gametes and the posthumous use of stored gametes and embryos have received more judicial attention in other common law jurisdictions than in New Zealand, particularly in relation to the collection and use of sperm. While the regulation of assisted reproductive technology in overseas jurisdictions differs from the HART Act, the issues are the same. They relate to consent to the collection and use of gametes from deceased persons, the legal status of stored gametes and associated rights of the gamete providers, and the status, welfare and rights of the resulting children. The United Kingdom and the four Australian states that have adopted assisted reproductive technology legislation provide a range of views on each of these issues that are worth consideration in any development of regulation of posthumous reproduction in New Zealand. ${ }^{102}$

\section{A Collection of Gametes from Comatose and Deceased Persons}

Australia and the United Kingdom differ from New Zealand in not including the collection of gametes in their assisted reproductive technology statutes. Those statutes are concerned only with the preservation, storage, use and disposal of gametes and embryos. In Australia the collection of ova and sperm from deceased persons comes within the definition of "tissue" in their human tissue statutes. ${ }^{103}$ Compliance with the consent requirements in those statutes would suffice to authorise the removal of sperm or eggs from a deceased man or woman. ${ }^{104}$ In the United Kingdom, gametes are excluded from the scope of its Human Tissue Act 2004. ${ }^{105}$

Where the collection of gametes is not covered by statute, the common law applies. In $L v$ Human Fertilisation and Embryology Authority, a decision of the High Court of England and

102 The Australian Capital Territory, Queensland and Tasmania do not have assisted reproductive legislation, and the Northern Territory is guided by South Australia's legislation. The National Health and Medical Research Council has issued Ethical Guidelines on the Use of Assisted Reproductive Technology in Clinical Practice and Research (2007).

103 "Tissue" is defined in all of the Australian statutes to include a substance extracted from a human body. Sperm and ova are excluded from that definition only for purposes of donation of tissue by living persons: Human Tissue Act 1982 (Vic), ss 3 and 5; Human Tissue Act 1983 (NSW), ss 4 and 6; Human Tissue and Transplant Act 1982 (WA), ss 3 and 6; Transplantation and Anatomy Act 1979 (Qld), ss 4 and 8; Transplantation and Anatomy Act 1983 (SA), s 5 and 7; Human Tissue Act 1985 (Tas), ss 3 and 5; Transplantation and Anatomy Act 1978 (ACT), ss 2 and 6; and Transplantation and Anatomy Act (NT), ss 4 and 6. However, not all jurisdictions have relied on this authority. For example, Queensland's Forensic and Scientific Services has issued Guidelines for removal of sperm from deceased persons for IVF: consent, authorization and role of IVF organisations (2012) in which it recommends that authorisation be sought from the Supreme Court, even where the deceased had given prior written consent.

104 AB v Attorney-General for the State of Victoria, above n 67; Re Edwards, above n 5, at 203-205; Re Section 22 Human Tissue and Transplant Act 1982 (WA), ex $p$ C, above n 5.

105 Human Tissue Act 2004, s 53. 
Wales, Charles J's provisional view was to doubt whether there was anyone who could consent on behalf of an incompetent person to the retrieval of gametes for purposes of posthumous reproduction. ${ }^{106}$ The Mental Capacity Act 2005 (UK) prohibits anyone appointed under that Act from giving consent on behalf of an incapacitated person to procedures covered by the Human Fertilisation and Embryology Acts 1990 and 2008 (UK). ${ }^{107}$ Such a clear statutory prohibition could also oust the court's inherent parens patriae jurisdiction. If the person was dead, the well-settled common law rule that there is no property in a body would preclude anyone from consenting to the removal of gametes from a body. ${ }^{108}$

The Australian courts do not hold the same restricted view of their jurisdiction to make these kinds of orders. As mentioned earlier, when authorisation has been sought in respect of a comatose or deceased person and the application was not made under the human tissue legislation, the courts have generally relied on their inherent jurisdiction to declare the removal of gametes lawful. ${ }^{109}$ They have also justified their decision on the basis of their power under their state's Supreme Court Rules to order that samples of property be taken for use in future proceedings, finding that tissue once separated from the body could be classified as property. ${ }^{110}$ Court approval for the future use of the gametes was a condition of the order authorising removal.

\section{B Posthumous Use of Gametes}

Perhaps the most well-known case about posthumous use of stored gametes is the application in England by Mrs Diane Blood to use her late husband's stored sperm to have his child. ${ }^{111} \mathrm{Mr}$ and

106 L v The Human Fertilisation and Embryology Authority, above n 5, at [144]-[161]. See also Sheila McLean "Post-mortem human reproduction: Legal and other regulatory issues" (2002) JLM 429.

107 Mental Capacity Act 2005, s 27(1)(h).

108 Despite this rule being founded on errors, it has become well established: Rohan Hardcastle Law and the Human Body (Hart Publishing, Oxford, 2007) at 25-28; and James Edelman "Property rights to our bodies and to their products" (paper presented to Australian Association of Bioethics and Health Law Conference, Perth, 3 October 2014) at 18.

109 Re Denman, above n 63; Fields v Attorney-General of Victoria, above n 66; Yv Austin Health, above n 5; and $R e H, A E$, above $\mathrm{n}$ 5. The courts departed from the earlier rulings in Re Gray, above n 5; and Baker v Queensland, above n 62, that there was no inherent jurisdiction to authorise the removal of tissue.

110 Roche v Douglas [2000] WASC 146, (2000) 22 WAR 331; S v Minister for Health (WA) [2008] WASC 262; Re Section 22 of the Human Tissue and Transplant Act 1982 (WA), ex p M [2008] WASC 276; Bazley v Wesley Monash IVF Pty Ltd [2010] QSC 118, (2010) 2 Qd R 207; and Re Edwards, above n 5. See also Hecht v Superior Court of Los Angeles (1993) 16 Cal App 4th 836, 20 Cal Rptr 2d 275; Yearworth v North Bristol NHS Trust [2009] EWCA Civ 37, [2010] QB 1; and Holdich v Lothian Health Board [2014] SLT 495. Edelman, above n 108, argues persuasively that there is no difficulty in principle with classifying gametes and other tissue separated from the human body as property. However, there may be important policy reasons for limiting the property rights.

111 Human Fertilisation and Embryology Authority, ex p Blood, above n 5. 
Mrs Blood had decided in late 1994 to try and start a family, but Mr Blood contracted meningitis in February 1995 and died within a few days. He was in a coma when the first sample of sperm was retrieved by electro-ejaculation. A second sample was taken the next day shortly before he was certified clinically dead. When Mrs Blood sought to use her late husband's sperm, the Human Fertilisation and Embryology Authority (the Authority) declined her request, because Mr Blood had not given written consent to the posthumous storage and use of his sperm, as required the Human Fertilisation and Embryology Act 1990 (UK). ${ }^{112}$ Both the High Court and the Court of Appeal agreed with the Authority that the clear language of the Act meant that Mrs Blood was prohibited from using her husband's sperm in the United Kingdom. ${ }^{113}$ The Court of Appeal did allow her appeal to export her husband's sperm to Belgium to enable her to receive treatment in a clinic in Brussels, because that accorded with European Community law. She has since used the sperm twice, giving birth to two sons.

Schedule 3 of the Human Fertilisation and Embryology Act 1990 (UK), as amended by the Human Fertilisation and Embryology Act 2008 (UK), imposes stringent requirements for consent to the storage and use of stored gametes and embryos. ${ }^{114}$ Consent must be given in writing and signed by the person giving consent. If the person is unable to sign because of illness, injury or disability, the consent may be signed by someone else at the direction of the person who is unable to sign and in the presence of that person and at least one witness who attests the signature. For the consent to be "effective", it must not have been withdrawn. ${ }^{115}$ Verbal consent will therefore not suffice, let alone consent inferred from words or conduct. ${ }^{116}$

112 Human Fertilisation and Embryology Act 1990 (UK), s 12(1)(c) and sch 3 require written consent that has not been withdrawn to the storage and use of gametes. The Act was amended in 2008 to require specific consent in writing from a man to the posthumous use of his sperm: Human Fertilisation and Embryology Act 2008 (UK), s 39. Technically, the storage of Mr Blood's sperm without his written consent was an offence under the Act: Human Fertilisation and Embryology Act 1990 (UK), ss 4(1)(a), 12 and 41 . No prosecution was brought because the license holder consulted throughout with the Authority on the unexplored legal situation, and humanity dictated that the sperm be retrieved and preserved and that full legal argument follow: Human Fertilisation and Embryology Authority, ex p Blood, above n 5, at 695.

113 R v Human Fertilisation and Embryology Authority, ex p Blood [1996] 3 WLR 1176 (QB).

114 The deceased's right to control what should be done with his or her stored gametes is one of several statutory exceptions to the common law rule that there is no property in a body.

115 Human Fertilisation and Embryology Act 1990 (UK), sch 3, para 1, as amended by Human Fertilisation and Embryology Act 2008 (UK).

116 For purposes of exporting gametes, however, the Human Fertilisation and Embryology Authority does have the power to make a special direction under s 24(4) of the Act. In $R$ (on the application of M) $v$ Human Fertilisation and Embrology Authority, above n 11, the parents of the late Ms AM sought such a direction authorising the export of AM's stored eggs to New York for fertilisation with an anonymous donor, and implantation into AM's mother. The application was declined because of lack of clear evidence of AM's wishes. 
The consent must specify the purposes for which embryos or gametes are to be used and what is to be done with them if the gamete provider dies or loses the capacity to vary the terms of the consent or withdraw consent. ${ }^{117}$ Prior to giving consent, the person must be given such relevant information as is proper and an opportunity to receive counselling about the implications of taking the proposed steps. ${ }^{118}$ The person must also be informed that he or she can vary the terms of the consent or withdraw consent until such time as the embryo is used in providing treatment services. ${ }^{119}$

Paragraph 5 of the schedule stipulates:

(1) A person's gametes must not be used for the purposes of treatment services unless there is an effective consent by that person to their being so used and they are used in accordance with the terms of the consent.

(2) A person's gametes must not be received for use for those purposes unless there is an effective consent by that person to their being so used.

It is clear from these provisions that posthumous use of gametes or stored embryos without the deceased's specific written consent to such use is prohibited in the United Kingdom. These consent requirements are unlikely to be met where death is sudden and unexpected. Collecting the gametes is pointless unless they can be used elsewhere to achieve a pregnancy, as Mrs Blood did. ${ }^{120}$

Assisted reproduction in Australia is a matter for each state and territory. Only New South Wales, South Australia, Victoria and Western Australia have adopted legislation regulating assisted reproductive technology. ${ }^{121}$ Their regulation of posthumous conception is not consistent. Victoria's legislation is the most developed. Its Assisted Reproductive Treatment Act 2008 (Vic) deals not only with the posthumous use of sperm by the deceased's surviving widow, but also covers the posthumous use of eggs by the deceased woman's surviving husband or male partner. As in the United Kingdom, Victoria requires written consent from the deceased for the posthumous use of his or her gametes, or an embryo created from his or her gametes. ${ }^{122}$ In addition, the proposed use must

117 Schedule 3, para 2(2).

118 Schedule 3, para 3.

119 Schedule 3, para 4.

120 As the Court noted in Lv The Human Fertilisation and Embryology Authority, above n 5.

121 Assisted Reproductive Technology Act 2007 (NSW) and Assisted Reproductive Technology Regulation 2009 (NSW); Assisted Reproductive Treatment Act 1988 (SA) and Assisted Reproductive Treatment Regulations 2010 (SA); Assisted Reproductive Treatment Act 2008 (Vic) and Assisted Reproductive Treatment Regulations 2009 (Vic); and Human Reproductive Technology Act 1991 (WA) and Human Reproductive Technology Directions 2004 (WA).

122 Assisted Reproductive Treatment Act 2008 (Vic), s 46. 
be approved by a Patient Review Panel and the person who is to undergo the treatment procedure must have received counselling. ${ }^{123}$ The requirement for written consent would prevent a widow like Jane in $\operatorname{Re} M$ from using her late husband's sperm for purposes of procuring a pregnancy in Victoria. Victoria also restricts the posthumous use of gametes or embryos to the deceased's partner or, in the case of a deceased woman, to her male partner using a surrogacy arrangement. ${ }^{124}$ That restriction would prevent Cameron Duncan's family from using his stored sperm.

New South Wales has less stringent requirements for posthumous use of gametes, which apply to both sperm and ova. ${ }^{125}$ While consent must be provided in writing, no further approval is required. ${ }^{126}$ Nor is use restricted to the gamete provider's spouse or partner. The woman receiving the treatment must consent in writing to using the gamete despite the death of the gamete provider being dead. ${ }^{127}$ As the deceased in Re Edwards had not consented in writing to the use of his gametes after death, his wife was unable to use them in New South Wales, even though he had asked his wife to promise him that she would have his baby if he died. ${ }^{128}$

South Australia also requires consent for the posthumous use of a man's sperm collected before he died. ${ }^{129}$ As in Victoria, it may only be used for the benefit of a woman who was his spouse or partner immediately before his death. ${ }^{130}$ The Act does not refer to posthumous use of gametes collected after the person's death. But nor does it prohibit such use. Western Australia requires written consent to the use of gametes generally and the consent must specify what should be done with the gametes if the provider loses capacity or dies. ${ }^{131}$ It does not otherwise deal specifically with posthumous conception.

To the extent that the statutes do not cover posthumous use of gametes, the National Health and Medical Research Council's Ethical Guidelines on the Use of Assisted Reproductive Technology in Clinical Practice and Research provide guidance. They require clearly expressed and witnessed

123 Sections 46(d) and 48.

124 Section 46(a).

125 Assisted Reproductive Technology Act 2007 (NSW), s 23 refers to posthumous use of "gametes" which s 4 defines as sperm or human ova.

126 Section 17.

127 Section 23.

128 Re Edwards, above n 5.

129 Assisted Reproductive Treatment Act 1988 (SA), s 9(1)(c)(iv).

130 Section 9(1)(c)(iv)(E).

131 Human reproductive Technology Act 1991 (WA), s 22(8). 
directions from the deceased consenting to the posthumous use of the gametes. ${ }^{132}$ The prospective parent must have received counselling about the consequences of such use, and the use must not diminish the fulfillment or the right of any child who may be born to knowledge of his or her biological parents.

As there is no legislation in Queensland regulating assisted reproductive technology, its fertility clinics rely on these guidelines. The lack of a clearly expressed directive authorising posthumous storage and use led the respondent in Bazley $v$ Wesley Monash IVF Pty Ltd to decline Mrs Bazley's request to continued storage of the sperm that her late husband had stored prior to cancer treatment. ${ }^{133}$ It also declined her request to release the sperm to her for treatment in the Australian Capital Territory, because that would be in breach of the rules in Queensland. Granting Ms Bazley's application for continued storage, the Supreme Court of Queensland referred to the growing body of case law rejecting the no property rule in relation to body parts and tissue removed from a body. Accordingly, it held that the six straws of semen held by the clinic belonged to the husband while he was alive and, following his death, they were part of his estate. As his personal representative, Ms Bazley had the right to determine whether they should be destroyed or returned to her. While that decision entitled her to take the sperm, it did not authorise her to use it to procure a pregnancy in Queensland. She would have to find a jurisdiction that would allow her to use the sperm without her deceased husband's written consent.

\section{Legal Status of a Posthumously Conceived Child}

After Mrs Blood gave birth to her first son, she encountered a further hurdle: she was unable to register her late husband as the son's father. The provisions of the Human Fertilisation and Embryology Act 1990 (UK) that applied at the time prevented any man whose sperm was used to create a child after his death from being treated as the father of the child. ${ }^{134}$ When Mrs Blood and another widow filed proceedings, claiming that the Act breached their right to private and family life under the European Convention of Human Rights, ${ }^{135}$ the Legislature adopted the Human Fertilisation and Embryology (Deceased Fathers) Act 2003 (UK) to enable a deceased man to be registered as the father of the child. He must have consented in writing to the posthumous use of his sperm by his widow and to being treated as the father of any resulting child. Parentage is solely for the purpose of entering his details on the child's birth register, not for any other purpose. His widow must elect in writing within 42 days of the child's birth to her late husband being treated as the

132 National Health and Medical Research Council Ethical Guidelines on the use of Assisted Reproductive technology in Clinical Practice and Research (2007) at [6.15].

133 Bazley $v$ Wesley Monash IVF Pty Ltd, above n 110.

134 Human Fertilisation and Embryology Act 1990 (UK), s 28(6).

135 Convention for the Protection of Human Rights and Fundamental Freedoms 213 UNTS 222 (opened for signature 4 November 1950, entered into force 3 September 1953). 
child's father. ${ }^{136}$ If she fails to make the election or if the conditions for the man being registered as the father are not met, the child will be deemed to have no father. If she had re-partnered when she used her late husband's sperm to create the child, her new husband or partner will be the father of the child unless he did not consent to the procedure. ${ }^{137}$

Most of the Australian jurisdictions do not specifically address the parentage of a posthumously conceived child. As in New Zealand, their Acts are aimed at regulating the status of a child created by means of assisted reproductive technology during the lifetime of both parties. ${ }^{138}$ Their references to a married woman and the use of the present tense suggest that the child was conceived while both gamete providers were alive. Only South Australia and Victoria deal specifically with the parentage of a posthumously conceived child. ${ }^{139}$

South Australia presumes the deceased sperm provider to be the father of the child if he was the birth mother's husband or partner immediately before his death, and he had consented to the use of his sperm for the purposes of the fertilisation procedure. He is then conclusively presumed to have caused the pregnancy and, unlike the United Kingdom, his parentage is not limited to registration of the child's birth. ${ }^{140}$ Posthumous parenthood in Victoria's Status of Children Act 1974 (UK) provides not only for a deceased man to be registered as the child's father; it also allows a deceased woman to be registered as the child's mother. ${ }^{141}$ Parentage in Victoria is solely for the purpose of entering the deceased parent's details on the register, not for any other purpose. ${ }^{142}$

\section{Succession Rights}

Australia has been reforming its succession laws in an attempt to bring about uniformity. ${ }^{143}$ Its Model Intestacy Bill, which some states have adopted, grants intestate rights to an unborn child only if it was in the uterus of the mother when its father died. ${ }^{144}$

136 The current provision is in Human Fertilisation and Embryology Act 1990 (UK), s 28(5A) for married couples and in s $28(5 \mathrm{~B})$ for unmarried couples. If the conditions in these provisions are not met, s 28(6) applies: the deceased man will not be the father of the child.

137 Human Fertilisation and Embryology Act 1990 (UK), s 28(5A) and s 28(5B) are subject to s 28(2) and s 28(3).

138 Status of Children Act 1996 (NSW), s 14; Parentage Act (ACT), s 11; Artificial Conception Act 1985 (WA), s 6; Status of Children Act (NT), s 5D; Status of Children Act 1978 (Qd) ss 17-19; and Status of Children Act 1974 (Tas), s 10C.

139 Family Relationships Act 1975 (SA), s 10C(5); Status of Children Act 1974 (Vic), ss 37-40.

140 Family Relationships Act 1975 (SA), s 10C(5).

141 Status of Children Act 1974 (Vic), ss 37-40.

142 Section 40.

143 The Standing Committee of Attornies-General initiated the Uniform Succession Laws Project in 1991. 
The purpose of this requirement is to exclude stored embryos from the class of potential intestate heirs and thus avoid an indefinite delay in the administration and distribution of the estate. ${ }^{145}$ The same restriction applies to the eligibility of a child to claim family provision. ${ }^{146} \mathrm{~A}$ posthumously conceived child thus has no right to succeed on intestacy of the deceased parent or to make a claim against the deceased parent's estate under the family provision legislation. Whether the child has rights under the deceased's will depends on the terms of the will. ${ }^{147}$

\section{KEY ISSUES AND PROPOSED SOLUTIONS}

The review of New Zealand's regulation of posthumous conception revealed that it is uncertain, ambiguous and incomplete. The brief discussion of recent developments in Australia and the United Kingdom shows different approaches to several of the issues arising in posthumous reproduction. There are nonetheless a number of consistent themes in the legal developments that have occurred thus far.

\section{A Welfare of the Child}

Posthumous conception is not prohibited in any of the jurisdictions discussed in this article, including New Zealand. ${ }^{148}$ Concerns about the child growing up without one of its biological parents being present have been raised. ${ }^{149}$ However, as Atkinson $\mathrm{J}$ commented in Re Denman, "children have been born without fathers for a very long time". ${ }^{150}$ Even if the child was conceived naturally, its father may have died or deserted the mother before the child's birth. Furthermore,

144 New South Wales Law Reform Commission Uniform Succession Law: Intestacy (R116, 2007); and implemented the proposal in relation to unborn children in its Succession Act 2006 (NSW), s 3(2).

145 See for example Estate of $K$ (1996) 5 Tas R 365.

146 The Succession Act 2006 (NSW) defines eligibility in s 57 to include a "child of the deceased person". The restricted definition of a "child" in s 3(2) applies equally to the family provision sections of the Act.

147 Status of Children Act 1974 (Vic), s 40(2) exempts an express provision in the deceased's will from the general rule that the child is not to be treated as a the child of the deceased for any purpose other than registration of the child's birth.

148 Human Assisted Reproductive Technology Order 2005, sch, pt 2, cl 5 permits posthumous use of sperm. See also the Advisory Committee on Assisted Reproductive Technology's Guidelines on the Use, Storage and Disposal of Sperm from a Deceased Man (2000). Victoria's Infertility Treatment Act 1995 (Vic), s 43 prohibited the posthumous use of gametes, but that prohibition was gradually removed. Australia's National Health and Medical Research Council's Ethical Guidelines on Assisted Reproductive Technology (1996) at [3.2.6] also stated that posthumous use of gametes was ethically unacceptable and should be prohibited. Those Guidelines have also been amended to permit posthumous use of gametes.

149 For example in MAWv Western Sydney Area Health Service, above n 52.

150 Re Denman, above n 63, at 597. See also Re Edwards, above n 5, at 143-144, where the Court comments that circumstances had changed significantly in the decade since MAW $v$ Western Sydney Area Health Service, above n 52, was decided. 
single women commonly receive assisted reproductive treatment to produce a child, and single persons may apply to adopt a child. ${ }^{151}$ The absence of the biological parent cannot in itself be a reason to prevent posthumous reproduction. The difference is that a posthumously conceived child will grow up in the knowledge that its biological parent was dead before conception occurred. While that is unusual and perhaps of concern to the child, the increase in the number of applications for retrieval and use of gametes after death suggests that posthumous conception is becoming more widespread and accepted by society. Nonetheless, as with all assisted reproductive procedures, the health and well-being of the child is the first principle of the HART Act and the unusual circumstance of a child being conceived after the death of one of its parents deserves special consideration. ${ }^{152}$

\section{B Consent}

Another consistent feature in the regulation of posthumous reproduction is the need for consent from the deceased to the posthumous use of gametes or embryos. There is a divergence of views about the requirements for an effective consent and the limits on consent. The English and Australian statutes require written consent from the deceased. The United Kingdom is especially prescriptive. By stipulating the content of written consent as well as the opportunity to receive counselling, sudden and unexpected deaths will generally be excluded, even in circumstances where there is clear evidence that the deceased had contemplated posthumous conception and verbally indicated consent. Form and process can thus defeat intent and deprive couples of the opportunity to conceive children posthumously using the gametes of the deceased spouse or partner.

There are obvious benefits in requiring consent to be in writing. Not only does it serve an evidentiary function, the formality of the process also impresses upon the person the significance of consenting to the possible conception or birth of a child after his or her death. Australia's National Health and Medical Research Council's Ethical Guidelines on the Use of Assisted Reproductive

151 M Henaghan, K Daniels and J Caldwell "Family law policy and assisted human reproduction" in Mark Henaghan and Bill Atkin (eds) Family Law Policy in New Zealand (4th ed, Wellington, LexisNexis, 2013) at ch 6. Professor Hutton of Fertility Associates Wellington was reported in The Dominion Post (Wellington, 15 August 2004) as saying that one-third of people using donor insemination were single women and another third were lesbian couples. After a complaint to the Human Rights Commission that some of the Advisory Committee on Assisted Reproductive Technology's guidelines discriminated on grounds of marital status and sexual orientation, the Advisory Committee on Assisted Reproductive Technology amended its guidelines to remove the discriminatory effects: Guidelines on Surrogacy involving Assisted Reproductive Procedures (2013) and Guidelines on Donation of Eggs or Sperm between Certain Family Members (2013).

152 Sarah Jones and Grant Gillett "Posthumous reproduction: consent and its limitations" (2008) 16 JLM 279 , where the authors argue that consent should not be the sole focus of ethical debate. A fuller picture should be examined, including the future life and prospects of the child, the needs and motivations of the mother and other pertinent factors. 
Technology in Clinical Practice and Research do not appear to insist on writing. ${ }^{153}$ A clearly expressed and witnessed direction could be made verbally. But even if verbal consent were sufficient, it would not assist widows like Jane in Re M or Mrs Blood from using their late husbands' sperm to conceive his child. Unlike Mr Edwards in New South Wales, whose wife promised him that she would still have their baby if he were to die, Jane and Tom never discussed the possibility of posthumous reproduction. ${ }^{154}$ Jane's husband's consent could at most be inferred from the fact that they were trying to have a second child and Jane's knowledge of her husband. Based on what she knew of his views and values, she was convinced that he would have agreed to her having another child using his sperm after his death, a full sibling for their first child. This sort of evidence is consistent with the approach to consent to treatment of an incompetent person in Right 7(4) of the Code of Rights.

The approach to consent to posthumous use of gametes has been cautious. It is only in the last decade that bans on posthumous use of gametes have been lifted. To impose stringent formal requirements on consent to protect the gamete provider is understandable. But with the increased number of applications for posthumous retrieval and use of gametes without written consent, it is appropriate to review the need for written consent and consider alternative mechanisms for protecting the interests of the gamete provider, the prospective parent and any resulting child. As part of this review, consideration should also be given to whether there is any scope for consent to be given by others for or on behalf of the gamete provider, as Cameron Duncan did when he authorised his mother to decide what use should be made of his stored sperm after his death.

There are also different views on whether posthumous use of gametes should be restricted to the deceased's spouse or partner. There appears to be little justification for such a limitation, especially not if the deceased had consented to his or her gametes being donated after his or her death, as Cameron Duncan appears to have done. Concerns about the proposed donation and use can be addressed by requiring approval from ECART.

The requirements for consent to the posthumous use of gametes will affect the consent requirements for collection of gametes from a comatose or deceased person. If written consent is required for the use of the gametes, there is little point in collecting the gametes in the absence of such consent. Leaving that practical point aside, there is lingering uncertainty about the legal foundation for authorising the removal of gametes from a person who lacks capacity to consent. If retrieval of gametes from comatose or deceased persons is to be permitted, then clarification of the

153 National Health and Medical Research Council Ethical Guidelines on the Use of Assisted Reproductive Technology in Clinical Practice and Research (2007) at [6.15]. See also Re Edwards, above n 5, at [118]. However, it seems that clinics in Queensland, at least, have construed the guidelines to require a written directive: Bazley v Wesley Monash IVF Pty Ltd, above n 110.

154 Re Edwards, above n 5. 
law is needed to provide certainty about authorisation for such procedures and the evidence necessary to establish the views of the deceased.

\section{Status and Rights of a Posthumously Conceived Child}

The legal status of posthumously conceived children is important, particularly for the child. Where the applications for posthumous use of a deceased husband's sperm have come before the courts, the widows have invariably wanted to have their late husband's child. That is also true for Jane. She wants the chance to have Tom's child, a full sibling for their first child. To that end, it is necessary to change the Status of Children Act 1969 in New Zealand to enable the deceased parent's particulars to be entered on the register of the child's birth if the deceased's spouse or partner uses the deceased's gametes to produce a child. As in Victoria, provision should be made not only for a deceased father to be registered, but also a deceased mother, whose eggs are used to produce a child for her surviving husband.

Victoria and the United Kingdom limit parenthood to registration. For all other purposes the deceased is deemed not to be the parent of the child. That avoids any complications in regard to succession, administration of estates and trusts. But that may be to the detriment of the posthumously conceived child. Time limits and the general limit on disturbing distributions should suffice to ensure efficient administration of trusts and estates.

\section{CONCLUSION}

Jane's application in $\operatorname{Re} M$ to collect Tom's sperm and the application to use Cameron Duncan's sperm have brought into sharp focus some of the problems with the current regulation of posthumous reproduction in New Zealand. Case law and statutory regulation in Australia and the United Kingdom provide valuable insights into the complexities of posthumous reproduction. They also reveal the adverse effects of legislative constraints on individual applicants wanting to have their loved one's child and the courts' openness to arguments that seek to sidestep those constraints. Their experience calls into question the need for some of the constraints.

New Zealand has to develop its own response to the issues identified in this article. Some of the responses will require legislative reform, such as the Status of Children Act 1969 to clarify the status of children conceived after their biological parent's death, and s 12 of the HART Act 2004 in relation to minors. Other responses will be determined by ACART after consultation with the public and the Minister of Health. Consistent with the HART Act's purpose of securing the benefits of assisted reproductive technology, serious consideration should be given to adopting guidelines that avoid unnecessary constraints and give ECART sufficient flexibility to take account of a range of factors when deciding individual cases. Such an approach would be consistent with the navigation points that Bill Atkin and Paparangi Reid first proposed more than two decades ago, and with the values that Atkin has espoused ever since. 